\title{
An Overview of Personal Luxury Brands Consumption in Malaysia
}

Mohamad Idham Md Razak, Zailin Zainal Ariffin, Mohd Nor Yahaya, Irzan Ismail

To Link this Article: http://dx.doi.org/10.6007/IJARBSS/v11-i3/8483

DOI:10.6007/IJARBSS/v11-i3/8483

Received: 23 January 2021, Revised: 27 January 2021, Accepted: 18 February 2021

Published Online: 08 March 2021

In-Text Citation: (Razak et al., 2021)

To Cite this Article: Razak, M. I. M., Ariffin, Z. Z., Yahaya, M. N., \& Ismail, I. (2021). An Overview of Personal Luxury Brands Consumption in Malaysia. International Journal of Academic Research in Business and Social Sciences, 11(3), 566-573.

\section{Copyright: (c) 2021 The Author(s)}

Published by Human Resource Management Academic Research Society (www.hrmars.com)

This article is published under the Creative Commons Attribution (CC BY 4.0) license. Anyone may reproduce, distribute, translate and create derivative works of this article (for both commercial and non-commercial purposes), subject to full attribution to the original publication and authors. The full terms of this license may be seen at: http://creativecommons.org/licences/by/4.0/legalcode

Vol. 11, No. 3, 2021, Pg. 566 - 573

Full Terms \& Conditions of access and use can be found at http://hrmars.com/index.php/pages/detail/publication-ethics 


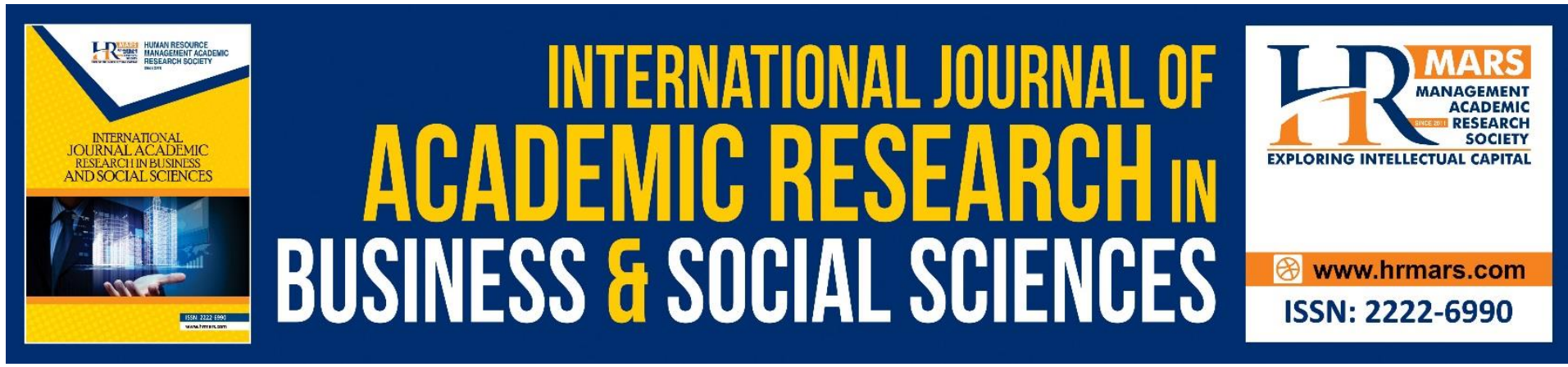

\title{
An Overview of Personal Luxury Brands Consumption in Malaysia
}

\section{Mohamad Idham Md Razak, Zailin Zainal Ariffin, Mohd Nor Yahaya}

Faculty of Defence Studies \& Management, National Defence University of Malaysia Email: iedham@uitm.edu.my, zailin@upnm.edu.my,mohdnor@upnm.edu.my

\section{Irzan Ismail}

Faculty of Business and Management, Universiti Teknologi MARA Melaka Campus

Email: irzan@uitm.edu.my

\begin{abstract}
The goal of this study was to increase the understanding of the concepts and variables affecting the procurement of high-end goods among Malaysians. In addition, this study also incorporates a theoretical framework using secondary sources based on previous research. As moderating factors influencing the purchase of luxury goods, the keywords include financial value, practical value, personal value, social value, country of origin and consumer shopping experience. Thus, this study revealed that marketers and luxury brand operators could build successful promotional strategies and programs to influence consumers in Malaysia's purchasing intent towards subtle luxury fashion products. The unassuming purchasing operation can also be applied to several other luxury product categories and service sectors by retailers.
\end{abstract}

Keywords: Financial Value, Functional Value, Individual Value, Social Value, Country Of Origin, Customer Shopping Experience

\section{Introduction}

This study shows that in the future, the outcry for luxury goods is encouraging among Malaysians. Research figures show a 7\% increase from 1995 to 2013, according to Kapferer and Laurent (2016), and this growth is projected to rise from $4 \%$ to $5 \%$ by 2020 . The taste of luxury products in Malaysia keeps finding a way into the hearts of locals, Euromonitor International Limited (2019) suggests. The reinstatement of the Sales and Service Tax for 2018 contributes to the emphasis on luxury goods. The rise of independent retail outlets such as Tom Ford Beauty, Yves Saint Laurent Beaute and Maison Christian Dior is also a major contributing factor to the growth of Malaysia's high-fashion industry.

The reason people buy high-end products today is to demonstrate wealth, prosperity, achievement, social status, according to Mamat et al. (2016), other than just being satisfied with a higher product quality. Overall, this study will discuss factors that influence the 
purchasing trend of personal luxury goods in Malaysia. The independent variable would include the country of origin, while the mediating variable would be consumer shopping experience.

According to a study conducted by Lim et al. (2012), it is implied that there should only be three essential values to be adopted in the study on consumer behavior towards luxury which are functional values, emotional values and social values. Future researchers should be able to establish keen exploration on other consumer values associated with luxury products that were not embraced in this study. Furthermore, due to the empirical research approach used to capture the value dimensions that constitute with luxury brands in the previous study, there were several limitations discovered (Vigneron \& Johnson, 2004). This is due to the fact that majority of the research concerning this subject are mostly conceptual (Vigneron \& Johnson, 1999). However, past researchers have established a perspective that the value dimensions that associate with luxury brands are very vague in the consequence of underinvestigation and poor representation of knowledge concerning this particular field (Tynan et al., 2010). Therefore, this research aimed to establish the gap in the literature concerning this juncture of study by developing and empirical testing on a model for value dimensions of luxury brands which can subsequently extend the validity and reliability of the theoretical foundations (Shukla \& Purani, 2012). Furthermore, the value dimensions impact of luxury brands towards a veritable consumers purchase behaviour in Malaysia will also be explored in this research.

\section{Literature Review}

It is possible to group goods into three branches, namely mediocre goods, common goods and luxury goods. Differences between middle- and high-income customers in the buying power of products are partly related to their needs and requirements. The expenditure increases according to the financial stability of a person, thus setting the extravagant value level for the product (Bilge, 2015). The term luxury, derived from the Latin word luxury, implies soft or extravagant life, overindulgence, and sumptuousness, comfort and abundance, according to Bilge (2015). Likewise, as Vigneron and Johnson (1999) suggest, luxury can be depicted as a revered and high-value brand.

From an economic point of view, on the other hand, how an item is categorized in the market as luxury rests on its elasticity. Items may be categorized as luxury goods if the revenue elasticity of their demand is greater than other items. In short, the higher the family income, the higher the distribution or cost of luxury goods (Case et al., 2019).

Luxury goods are definitely closely linked to high prices. Feasibly, because the lower-income class does not buy these items, the financially affluent subset of consumers therefore prefer to buy luxury goods due to the sense of exclusivity inherent in the luxury products. The price of the luxury good itself actually plays a major role in determining the status of a person in society. As per Lim et al. (2012), the purchase of luxury goods by consumers is owing to their belief that designers produce these goods and are of the highest quality. Similarly, Wiedmann et al. (2007) claim that the authenticity, aesthetic value, and practicality of brands and luxury goods on numerous occasions impact the consumer's decision to acquire these goods. 
The need and tendency to indulge in high-end goods is also influenced by the production of the individual's reputation. Ergo, the general outlook of the luxury brand would produce the expected image any time a consumer buys luxury goods. Consumers of luxury goods seem to be impressed, according to Bilge (2015), whenever the acquired luxury brand is able to produce the desired image that adequately meets the fashion aura of the consumer. In addition, luxury goods ownership, notably by women, shows the power and status quo of society. This is evident among Asians, as these people adhere to the expectations of the society and environment in which they live. Recent research shows that Asia has the largest number of buyers of luxury goods due to the pressure of the external climate. At least one luxury product, also known as Coach, Longchamp, Prada, Christian Dior, Burberry and Louis Vuitton, is prominent among Asians aged 21 and above (Lim et al., 2012).

Country-of-origin is usually referred to in any product as 'made in' or 'manufactured in' as it refers to the country from which the products originated. In moulding the buyer's purchasing decision, the country of the retailer plays an important role. For example, Louis Vuitton branded French products are more alluring to buyers than products manufactured in China because of their brand and significance. This is because France, as a nation that produces this prestigious brand, is famously centred on the subject. Furthermore, Wiedman et al. (2007) indicated that the place of origin may have a positive or negative impact on consumer purchasing decisions. Nevertheless, there is a lack of empirical research linking the relationship between the origin country of luxury goods and the consumer's experience in decision-making on product purchasing.

Clearly, the key factors influencing the decision-making of shoppers on purchasing goods have been identified, such as shopping experience, the state and functionality of the outlet and the services of the seller, according to current research. This study looks forward to contribute to the mediator variable of positive relationships between environmental variables that may affect consumer perception and behaviour during the shopping process (Ogruk et al., 2012). Figure 2.1 shows the conceptual framework for this study:

Independent Variables

Mediating Variable

Dependent Variable

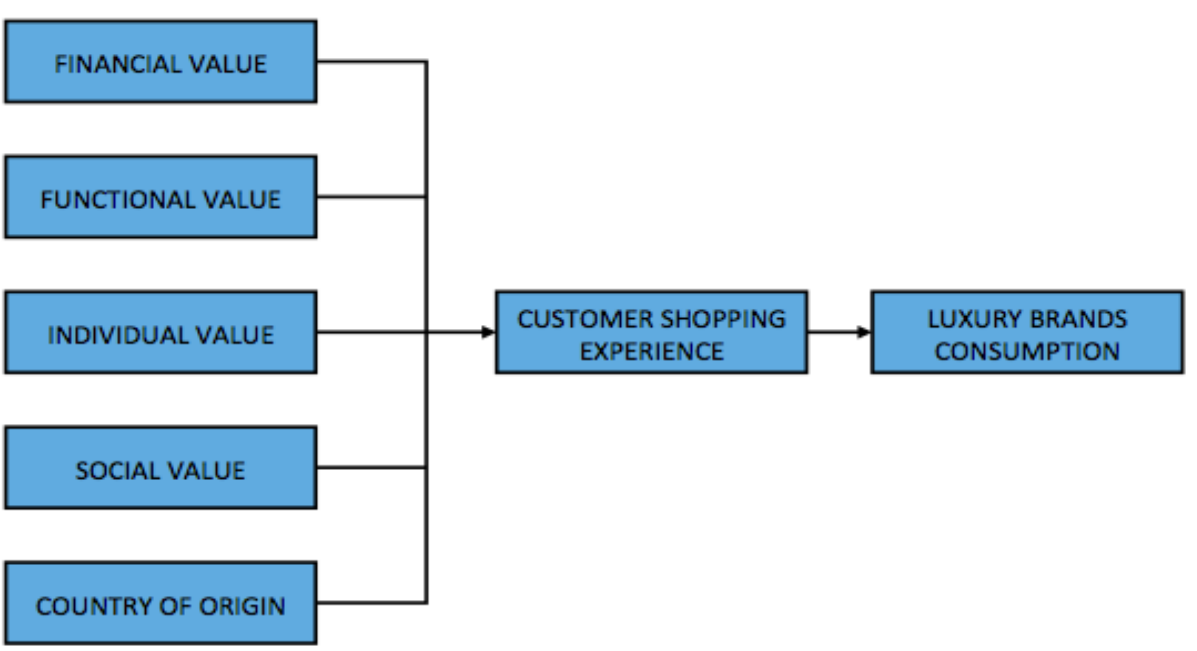

Figure 2.1: Conceptual Framework 


\section{Research Objective}

1. What is the relationship between financial value, functional value, individual, social value, country of origins, and customer shopping experience towards personal luxury brands consumption?

2. Does customer shopping experience will influence customers towards personal luxury brands consumption?

\section{Methodology}

Based on quantitative techniques, the nature of this study helps to capture the interpretation of participants and to analyze the degree to which the variables vary from each other, highlighting the relationships between variables. Consequentially, explanations of the study flow and the variables involved will be explained based on the findings of this analysis (Creswell, 2014). This study will therefore advocate elements such as financial value, functional value, individual value, social value and country of origin that contribute to the usage of personal luxury brands. Therefore, the relevance of consumer shopping experience will improve relations between independent variables and dependent variables. Using a selfadministered survey, this study embarks on a quantitative approach.

The researcher used closed-ended questions to collect the data. Snowball sampling was used to extend one hundred of fifty (150) questionnaires. The latter confirms that a total of 142 completed questionnaires have been received, all of which comply with the standards established. Sandelowski (1995) noted that the sample size for quantitative research is adequate for about 100-200. The researcher outlines the purpose of the study and also offers specific instructions for the survey to be conducted. Immediately upon completion, the questionnaires were collected. Finally, the investigator uses SPSS 26.0 and PLS-SEM statistical tools to figure out the relationship with the variables.

\section{Findings}

The analysis by Sekaran and Bougie (2016) showed that the value of Cronbach's Alpha, which is less than 0.60 , is considered low, while the value is considered appropriate at 0.70 , and the value is considered good at 0.80 and above. All scales fell under the value category of 0.80 and above, based on Table 4.1. Hence, implying that it is measured as good.

Table 4.1: Cronbach's Alpha for the Study Measures

\begin{tabular}{lc}
\hline \multicolumn{1}{c}{ Construct } & Cronbach's Alpha \\
\hline Financial Value & 0.944 \\
Functional Value & 0.865 \\
Individual Value & 0.813 \\
Social Value & 0.855 \\
Country of Origin & 0.905 \\
Shopping Experience & 0.873 \\
Luxury Consumption & 0.855 \\
\hline
\end{tabular}

It is proven that the design of the measurements used in this study is accurate and true based on the measurement models used. Therefore, as described in a study by Hair et al. (2017), the next step is to evaluate the degree of collinearity of the structural model. In order to avoid the possibility of $\beta$ s of independent variables as skewed due to a high degree of collinearity 
among predictor constructs, it is important to examine collinearity when inspecting the structural model. For the collinearity evaluation, SPSS was used.

Table 4.2: Assessment of Multicollinearity

\begin{tabular}{lcc}
\hline Construct & $\begin{array}{c}\text { Customer Shopping } \\
\text { Experience }\end{array}$ & $\begin{array}{c}\text { Personal Luxury Brands } \\
\text { Consumption }\end{array}$ \\
\hline Country of Origin & 1.342 & 1.421 \\
Customer Shopping Experience & - & 1.428 \\
Financial Value & 1.559 & 1.574 \\
Functional Value & 1.447 & 1.447 \\
Individual Value & 1.527 & 1.672 \\
Personal Luxury Brands Consumption & - & - \\
Social Value & 1.463 & 1.512 \\
\hline
\end{tabular}

Table 4.3: Coefficient of Determination

\begin{tabular}{lr}
\hline & R \\
Construct & Square \\
\hline Customer Shopping Experience & 0.3 \\
Luxury Brands Consumption & 0.542 \\
\hline
\end{tabular}

The $R^{2}$ (Coefficient of determination) value is used to assess the structural model, as shown in Table 4.2. The coefficient analyses the accuracy of predictions and is determined by means of the square correlation between the actual and predictive values of the endogenous construct defined. The $R^{2}$ values, as reported by Hair et al. (2017), both reflect the amount of variance in the exogenous constructs associated with the endogenous constructs mentioned and the combination of the effects of the exogenous variables on the latent endogenous variables. In this research, Kuala Lumpur's endogenous variables, namely consumer shopping experience and consumption of luxury goods, have $\mathrm{R}^{2}$ values of 0.3 and 0.542 , respectively. Therefore, there is a predictive significance to the reality of the structural model built in this report.

Table 4.4: Hypothesis Testing

\begin{tabular}{lcccccc}
\hline Construct & $\begin{array}{c}\text { Original } \\
\text { Sample } \\
(\mathbf{O})\end{array}$ & $\begin{array}{c}\text { Sample } \\
\text { Mean (M) }\end{array}$ & $\begin{array}{c}\text { Standard } \\
\text { Deviation } \\
\text { (STDEV) }\end{array}$ & $\begin{array}{c}\text { T Statistics } \\
(\text { IO/STDEV }\end{array}$ & Palues & Decision \\
\hline Country $\rightarrow$ Consumption & 0.094 & 0.087 & 0.072 & 1.31 & 0.1900 & Rejected \\
Experience $\rightarrow$ Consumption & 0.244 & 0.241 & 0.066 & 3.717 & 0.0000 & Accepted \\
Financial $\rightarrow$ Consumption & 0.065 & 0.073 & 0.078 & 0.844 & 0.3990 & Rejected \\
Functional $\rightarrow$ Consumption & 0.011 & 0.02 & 0.09 & 0.127 & 0.8990 & Rejected \\
Individual $\rightarrow$ Consumption & 0.128 & 0.128 & 0.089 & 1.442 & 0.1490 & Rejected \\
Social $\rightarrow$ Consumption & 0.428 & 0.429 & 0.082 & 5.233 & 0.0000 & Accepted \\
\hline
\end{tabular}

$* * p<0.01, * p<0.05$

Table 4.4 presents the path coefficients $(\beta)$, and their significant values in Malaysia. Several relationships (path coefficients) were found to be significant. Based on Table 4.4, the 
significant direct path coefficient is customer shopping experience $\rightarrow$ personal luxury brands consumption and social value $\rightarrow$ personal luxury brands consumption.

Table 4.5 Hypothesis Testing on Mediation

\begin{tabular}{|c|c|c|c|c|c|c|c|c|}
\hline Construct & & $\begin{array}{l}\text { Origina } \\
\text { Sample }\end{array}$ & $\begin{array}{l}\text { Sample } \\
\text { Mean }\end{array}$ & $\begin{array}{c}\text { Standar } \\
\mathbf{d} \\
\text { Deviatio } \\
\mathbf{n}\end{array}$ & $\begin{array}{c}\text { T } \\
\text { Statisti } \\
\text { CS }\end{array}$ & $\begin{array}{c}\mathbf{P} \\
\text { Value } \\
\mathbf{s}\end{array}$ & $\begin{array}{l}\text { Decision } \\
\mathrm{s}\end{array}$ & VAF \\
\hline $\begin{array}{l}\text { Country } \rightarrow \text { Experience } \\
\text { Consumption }\end{array}$ & $\rightarrow$ & 0.057 & 0.058 & 0.029 & 1.975 & 0.048 & $\begin{array}{l}\text { Accepte } \\
\text { d }\end{array}$ & $60.42 \%$ \\
\hline $\begin{array}{l}\text { Financial } \rightarrow \text { Experience } \\
\text { Consumption }\end{array}$ & $\rightarrow$ & -0.025 & -0.025 & 0.023 & 1.090 & 0.276 & Rejected & $\begin{array}{c}\text { Not } \\
\text { applicabl } \\
\text { e }\end{array}$ \\
\hline $\begin{array}{l}\text { Functional } \rightarrow \text { Experience } \\
\text { Consumption }\end{array}$ & $\rightarrow$ & 0.000 & 0.002 & 0.022 & 0.006 & 0.995 & Rejected & $\begin{array}{c}\text { Not } \\
\text { applicabl } \\
\text { e }\end{array}$ \\
\hline $\begin{array}{l}\text { Individual } \rightarrow \text { Experience } \\
\text { Consumption }\end{array}$ & $\rightarrow$ & 0.078 & 0.077 & 0.028 & 2.760 & 0.006 & $\begin{array}{l}\text { Accepte } \\
\text { d }\end{array}$ & $21.43 \%$ \\
\hline $\begin{array}{l}\text { Social } \rightarrow \text { Experience } \\
\text { Consumption }\end{array}$ & $\rightarrow$ & 0.045 & 0.046 & 0.023 & 2.009 & 0.045 & Rejected & $51.11 \%$ \\
\hline
\end{tabular}

Note: $t$-value $>1.96$

Table 4.5 describes the data collected from the samples in Malaysia and reveals that the indirect path of the country of origin $\rightarrow$ customer shopping experience $\rightarrow$ personal luxury brands consumption has a VAF value of $60.42 \%$ whereby it can be assumed that the customer shopping experience only mediates partially on the afore path mentioned. Next in the list is the indirect path of the individual value $\rightarrow$ customer shopping experience $\rightarrow$ personal luxury brands consumption with a VAF value of $21.43 \%$. This indirect path is determined to have a partial mediation occurring. Finally, the indirect path of social value $\rightarrow$ customer shopping experience $\rightarrow$ personal luxury brands consumption having a VAF value of $51.11 \%$ is adjudge as an event of partial mediation.

\section{Conclusion and Future Research Directions}

This research aims to provide insights into variables influencing Malaysia's consumption of personal luxury goods. Undoubtedly, this study shows that the majority of Kuala Lumpur respondents adapt to the social importance of personal luxury brands consumption and consumer shopping experience. The consumer shopping experience in Kuala Lumpur partly mediates the consumption of personal luxury goods by individual value, social value, and country of origin. In addition, in future studies, samples from western nations should be considered as such a comparison will help researchers understand administrative implications and consumer buying patterns between different countries. This research is limited to one form of luxury commodity, which is a result of luxury fashion. Future research should address different constituents in the field of luxury products such as premium vehicles, fine foods, fine wine or luxury service industries such as luxury hotels, luxury cruises, eventually educating people on the discretionary actions of these industries. 


\section{References}

Bilge, H. A. (2015). Luxury Consumption: Literature Review. Khazar Journal of Humanities and Social Science, 18 (1), 35-55.

Case, K. E., Fair, R. C., \& Oster, S. E. (2019). Principles of Microeconomics, Global Edition (13th ed.). United States: Pearson.

Creswell, J. W. (2014). Research Design: Qualitative, Quantitative, and Mixed Methods Approaches. (4 ${ }^{\text {th }}$ ed.). United States: Sage.

Euromonitor International Limited. (2019). Luxury Goods in Malaysia. Retrieved on 12 Dec 2020, https://www.euromonitor.com/luxury-goods-in-malaysia/report.

Glare P. W. (2012). Oxford Latin Dictionary (2nd ed.). Oxford: Oxford University Press.

Hair, J. F., Hult, G. T. M., Ringle, C. M., \& Sarstedt, M. (2017). A Primer on Partial Least Squares Structural Equation Modeling (PLS-SEM) (2nd ed.). Thousand Oaks: Sage.

Kapferer, J. N., \& Laurent, G. (2016). Where do Consumers Think Luxury Begins? A Study of Perceived Minimum Price for 21 Luxury Goods in 7 Countries. Journal of Business Research, 69(1), 332-340.

Lim, W. M., Ting, D. H., Khoo, P. T., \& Wong, W. Y. (2012). Understanding consumer values and socialization: A case of luxury products. Management \& Marketing Challenges for The Knowledge Society, 7(2), 209-220.

Mamat, M. N., Noor, N. M., \& Noor, N. M. (2016). Purchase Intentions of Foreign Luxury Brand Handbags among Consumers in Kuala Lumpur, Malaysia. Procedia Economics and Finance, 35, 206-215.

Ogruk, G., Anderson, T. D., \& Nacass, A. S. (2018). In-Store Customer Experience and Customer Emotional State in the Retail Industry. Journal of Research for Consumers, 32, 110-141.

Sandelowski, M. (1995). Sample Size in Qualitative Research. Research in Nursing \& Health, 18(2), 179-183.

Sekaran, U., \& Bougie, R. (2016). Research Methods for Business: A Skill Building Approach (7th ed.). United Kingdom: John Wiley \& Sons Ltd Production.

Shukla, P., \& Purani, K. (2012). Comparing the Importance of Luxury Value Perceptions in Cross-national Contexts. Journal of Business Research, 65(10), 1417-1424.

Srinivasan, R., Srivastava, R. K., \& Bhanot, S. (2015). Influence of Financial Value on Purchase of Luxury Brands with Respect To Demographic Variables. IOSR Journal of Business and Management (IOSR-JBM), 17(2), 64-73.

Tynan, C., McKechnie, S., \& Chhuon, C. (2010). Co-creating Value for Luxury Brands. Journal of Business Research, 63(11), 1156-1163.

Vigneron, F., \& Johnson, L. W. (2004). Measuring Perceptions of Brand Luxury. The Journal of Brand Management, 11(6), 484-508.

Vigneron, F., \& Johnson, L. W. (1999). A Review and a Conceptual Framework of PrestigeSeeking Consumer Behavior. Academy of Marketing Science Review, 3 (1), 1-15.

Wiedmann, K., Hennigs, N., Siebels, A. (2007). Measuring Consumers' Luxury Value Perception: A Cross-cultural Framework. Academy of Marketing Science Review, 7, 234255.

Yang, R., Ramsaran, R. R., \& Wibowo, S. (2016). A Conceptual Model for Country-Of-Origin Effects. Asia Pacific Journal of Advanced Business and Social Studies, 2 (1), 96-116. 